\title{
THE IMPROVEMENT OF STUDENTS' WRITING IN RECOUNT TEXT THROUGH T-CHART STRATEGY AT THE ELEVENTH GRADE STUDENTS OF SMAN I SUNGGUMINASA
}

\author{
Ratu Yulianti Natsir \\ Universitas Muhammadiyah Makassar \\ ratuyulianti@gmail.com
}

\begin{abstract}
The objective of the research was to find out the improvement of the students achievement in writing ability through T-Chart strategy in term of content, organization, and language use. The researcher applied a pre experimental design with one group pre test and one group post test design. The subject of the research was the eleventh grade students of MAN 1 Sinjai Utara academic year 2015-2016. The sample consists of 26 students. The research was held in seventh meetings. The result of the data analysis showed that there was a significant difference between pre test and post test. The research findings indicated that T-Chart Strategy was effective to improve the students' writing ability in terms of content, organization, and language use. It was proved by the students' mean score in pre test was 32. 66 and post test was 73. 66. It showed that the students' writing skill in post test was higher than pre test. The value of t-test from content, organization, and language use was 21. 36 and it was greater than t-table 2. 060 at the level of significant $(p)=0.05$ and degree of freedom $(\mathrm{df})=26-1=25$, it was found that the result of t-test value was greater than t-table $(21.36>2$. 060). It is said that the null hypothesis $\left(\mathrm{H}_{0}\right)$ was rejected and the alternative hypothesis $\left(\mathrm{H}_{1}\right)$ was accepted.
\end{abstract}

Key Words: writing, recount text, T-chart

\begin{abstract}
Abstrak
Tujuan dari penelitian ini adalah untuk mengetahui peningkatan prestasi belajar siswa dalam kemampuan menulis melalui strategi T-Chart dalam hal isi, organisasi, dan penggunaan bahasa. Peneliti menerapkan desain pra eksperimental dengan satu kelompok pre test dan satu kelompok post test design. Subjek penelitian adalah siswa kelas XI SMP MAN 1 Sinjai Utara tahun 2015-2016. Sampel terdiri dari 26 siswa. Penelitian dilakukan pada pertemuan ketujuh. Hasil analisis data menunjukkan bahwa ada perbedaan yang signifikan antara pre test dan post test. Temuan penelitian menunjukkan bahwa Strategi T-Chart efektif untuk meningkatkan kemampuan menulis siswa dalam hal isi, organisasi, dan penggunaan bahasa. Terbukti dengan nilai rata-rata siswa dalam pre test adalah 32. 66 dan post test adalah 73. 66. Hal ini menunjukkan bahwa kemampuan menulis siswa dalam post test lebih tinggi daripada tes awal. Nilai $t$ test dari isi, organisasi, dan penggunaan bahasa adalah 21. 36 dan lebih besar dari $t$ tabel 2. 060 pada tingkat signifikan $(p)=0.05$ dan derajat kebebasan $(d f)=26-1=25$, ditemukan bahwa hasil nilai t-test lebih besar dari t tabel (21. 36> 2. 060). Dikatakan bahwa hipotesis nol (HO) ditolak dan hipotesis alternatif (H1) diterima.
\end{abstract}

Kata kunci: menulis, teks recount, T-chart

\section{RESEARCH BACKGROUND}

Writing is one of the English language skills that have an important role not only in formal situation but also informal one, sometimes people cannot verbalize their opinion, ideas or feelings but they can express them through writing. Some 
elements or components should get attention in writing are caused by many factors. One of them is complicated components of writing, namely: content, grammar, style, form, and mechanics. These components are related to another in order to produce good result writing.

In fact, this objective is very hard to achieve. Most of the students' skills are far away from their learning target. Writing is one of the four language skill that include listening, speaking, reading, and writing. It is an activity to combine words to form meaningful messages that the writer wants to express. Many students could not express their idea smoothly in written form. Although they had been given a topic to write, they could not automatically start their writing assignment. In other words, although they have written several lines, they mostly find difficulties to continue their writing.

Concerning the problems that the students faced when they tried to express their ideas into written form, a teacher should choose an appropriate technique in teaching recount text writing. One of the techniques which can be applied in teaching recount text writing is T-chart strategy. The researcher chose T-chart strategy as a technique to increase the students' ability in writing recount text because T-chart is the best way that makes sense to you, your kids, and your community. The T-Chart Strategy is very useful. Opportunities to describe a sequence of events come up all the time in school: in narrative fiction and non-fiction writing, in plot summaries for reading, in the steps of solving a math problem, in social studies when you recount an historical event, in science when you study chemical processes, and so on.

Based on the interview from the teacher of SMAN I Sungguminasa, the students have low ability in writing. According their teacher, it is happened because the students have poor score in writing proficiency. Although, the teacher has an approach of learning process in the classroom, but it could not make the students' interest. Based on the factual information and explanation above, the researcher conducts a study on writing entitles "The Improvement Students' Writing in Recount Text through T-Chart Strategy at the Eleventh Grade Students of SMAN I Sungguminasa".

\section{RESEARCH QUESTIONS}

Referring to the background above, the researcher herewith formulates the following main research questions:

1. How is the improvement of the students' writing in term of content through TChart Strategy at the eleventh grade students of SMAN I Sungguminasa?

2. How is the improvement of the students' writing in term of language use through T-Chart Strategy at the eleventh grade students of SMAN I Sungguminasa.

\section{REVIEW OF RELATED FINDINGS}

Some researchers have done studies in teaching vocabulary and its contribution of English teaching. Some of the findings are presented in the following section.

1. Erlik Widiyani Setyani (2010) states that research findings imply that the use of clustering technique can affect to the students' writing competence optimally. It is proved from the research finding showing that students who are taught using 
clustering technique have better writing skill than these who are taught using direct interaction.

2. Linda Litasari (2010) states that the picture series can improve the students' attention and motivation in writing lesson, therefore researcher is interested to find out whether the picture series can improve the skill of students.

\section{SOME PERTINENT IDEAS}

\section{What is writing?}

Writing is the foundation for life-long learning. One must be able to master this skill in order to facilitate the learning process. Writing is simply not enough; one must be able to understand what one has read and be able to apply the newly acquired knowledge for the benefits to be fully realized. In America, writing is taught mainly using a basal approach, involving "teacher directed (methodology) with a significant reliance on worksheets, rote learning, and minimal interaction of students" (Kirylo and Millet, 2000: 179). This teaching method has been proven to be only minimally effective, as students do not retain much of what they have written and incorrectly proficiency the material. Two goals of a successful writing are that students must be able to write on their own and understand what they have written. Teachers, likewise, must become better educators by learning and implementing writing strategies that will help students reach their goals (Kirylo and Millet, 2000: 180).

One of the challenges which teachers face is how to present information that can be processed successfully by students, particularly those who are categorized as special needs. Perhaps the most abstruse task for learning disabled students to execute is making connections with content in textbooks. Texts are not organized for the learning disabled; any student who is a passive learner, or one who "lack (s) skills for processing and organizing written and oral information" (DiCecco and Gleason, 2002: 306), requires explicit instruction and assistance with "making inferences, understanding relationships and connections, distinguishing main ideas from significant details, and understanding the gist of the passage" (DiCecco and Gleason, 2002: 306).

Based on the findings above, the researcher concludes that writing is a form of thinking and a way to product language that comes from our thought, By using writing, we can share our idea, feeling or anything that exist in our mind.

\section{Recount}

Recount is a one kinds of text in writing which retells events or experiences in the past. Its purpose is either to inform or to entertain the audience. There is no complication among the participants and that differentiates from narrative. Foo, et al (2008: vi) states that a recount is a piece of writing that tells events in a chronological sequence. A recount text is like a narrative text in that you have to write a story but in a recount the story is real. The story may be an event or a situation that took place on a particular day, and you are the narrator of the whole event.

\section{Concept of T-Chart Strategy}


$\mathrm{T}$ - Chart is an appropriate strategy to apply in teaching writing, because this strategy is designed to help students to improve their writing achievement in learning writing. According to Peha (2003:5) states that T - Chart is a strategy to help students clarify concepts or ideas and to give specific examples. The ideas to make two lists at the same time based on opposites. It means that the students create the different topic that is like " $\mathrm{T}$ " when they will start in writing on their paper. In addition, Boyle and Scanlon (2010:68), states that $\mathrm{T}$ - Chart is strategy that help students manage and organize their knowledge in respect to the specific features of different items or topics. In here, the students make a $\mathrm{T}$-chart list of the behaviors inside the left side of the $\mathrm{T}$, and write a description of what the behavior "looks and sounds like" on the right side. Moreover, Burton (2012:136) defines T - Chart as a strategy which the students make to compare and contrast two topics (e.g.,stories, historical figures types of clouds and shapes) using a T - chart and sticky notes. It indicates that the students have to analyze each topic and create a chart that represents their thinking in opposite meaning.

The T-Chart is a strategy to engage students with facts of events sequencing. It involves the students in pre-writing and after writing exercises to help the students construct meaning and develop insights about the events being explored. TransitionAction-Details is an excellent way to prepare for writing a narrative or recount piece. The students think of an incident or event he wants to tell others about, like the time he fell out of a tree and broke his/her arm. (Peha, 2003:38).

As we know that, a comprehension strategy promoted by Fournier and Graves (2002:31) is scaffolding, or "providing support to help learners bridge the gap between what they know and can do and the intended goal". Scaffolding is one of the most effective instructional procedures.

Example

TYPICAL-UNUSUAL T-CHART

LIKE

\begin{tabular}{l|l|} 
Things I really like a lot & Things I really can't stand \\
\hline \hline Pizza & All vegetables \\
The internet & Homework \\
Ice cream & Science \\
Music & Spelling test \\
Reading & Getting dressed up \\
My cat & Cleaning my room \\
Harry poter & Rainy days \\
Soccer & Being bored \\
\hline
\end{tabular}




\section{RESEARCH METHOD}

\section{Research Design}

This research applied a Pre-Experimental Research with one group pre-test and post-test design. The design of this research is present in the following table:

Table 3.1: Research Design

\begin{tabular}{|l|l|l|}
\hline 01 & $X$ & 02 \\
\hline
\end{tabular}

Where:

$01=$ Pre-test

$\mathrm{X}=$ Treatment

$02 \quad=$ Post-test

(Gay, 2006:252).

\section{Research Variables and Indicators}

The following variables of the research are:

1. Independent variable

Independent variable of the research is T-Chart Strategy in teaching recount text.

2. Dependent variables writing.

Dependent variables are the students' language use and content of recount

With the indicators are:

a. The indicators of language use are prepositions and conjunctions.

b. The indicator of content is sequence events.

\section{Population and Sample}

\section{a. Population}

The population of this research employed the eleventh grade students of SMA Negeri I Sungguminasa in academic year 2016/2017. It is consist of 2 class of XI IPA and 3 class of XI IPS. The students in XI IPA are 55 students and in XI IPS are 85 students, so that the total population are 140 students.

\section{b. Sample}

This research applied purposive sampling technique in which the eleventh grade students of SMA Negeri I sunguminasa. In this research, the researcher only takes one class to represent all of the population. Class XI IPA-1 was consisting of 26 students it was the sample of the research.

\section{Instrument of the Research}

The instrument of the research was writing test. Before treatment, the students asked to make a recount text based on their topic.

The pre test used to see the students' former writing ability. Then, the treatment used T-Chart Strategy. After that, posttest administrated to see the effect of the treatment. 


\section{Procedure of Collection Data}

\section{a. Pre-Test}

Before giving treatment, the researcher explained to the students about recount in general. The researcher explained the characteristic of recount text and generic structure of recount. The pre-test gave after the explanation. In pre-test the students asked to compose a recount text based on their topic. By seeing the result of the students' writing test, the researcher analyzed it to see the prior ability of the students in writing recount text.

b. Treatment

After giving the pre test the students got treat by using T-Chart Strategy. The treatment took place within 4 meetings and it takes 90 minutes for each meeting. In this case, the researcher took four meetings. This step, all of the activities was same. The researcher provided a different kind of activities for each meeting; the topic was a real topic that the students encountered in their daily life.

$\mathbf{1}^{\text {st }}$ meeting : Like-Hate (things you like and things you hate)

$2^{\text {nd }}$ meeting : Typical-Unusual (typical experiences that happen almost every day and unusual experiences that have happened only once or twice in your entire life.

$3^{\text {rd }}$ meeting : Fun-Have to (things you do for fun and things you do because you have to.

$4^{\text {th }}$ meeting : Regret-Proud of (things you regret and things you are proud of

Some of steps of treatments are:

1) The researcher explained the purpose and the rules of learning.

2) The researcher explained recount text and T-Chart Strategy.

3) The researcher gave the students to ask about material and strategy to write

4) The researcher gave topic and sheet T-Chart to the students.

5) The researcher did the monitoring of learning processes that occur through T-Chart Strategy.

c. Post Test

The post test conducted after treatment to find the students' writing skill. The researcher distributed the same form of writing test as used in pre test to check the result of the treatment in the students' writing skill. 


\section{Data Analysis}

The data from the students it was calculated in the mean score to find out the students writing ability

Table 3.2. Scoring rubrics of writing

\begin{tabular}{|c|c|c|}
\hline ASPECT & SCORE & PERFORMANCE DESCRIPTION \\
\hline \multirow[t]{4}{*}{ Content } & 4 & $\begin{array}{l}\text { The topic is complete and clear and details } \\
\text { relating to the topic. }\end{array}$ \\
\hline & 3 & $\begin{array}{l}\text { The topic is complete and clear but the detail are } \\
\text { almost relating to the topic. }\end{array}$ \\
\hline & 2 & $\begin{array}{l}\text { The topic is complete and clear but the detail are } \\
\text { not relating to the topic. }\end{array}$ \\
\hline & 1 & $\begin{array}{l}\text { The topic is not clear but the detail are not relating } \\
\text { to the topic. }\end{array}$ \\
\hline \multirow[t]{4}{*}{ Organization } & 4 & $\begin{array}{l}\text { Identification is complete and description are } \\
\text { arranged with proper connection. }\end{array}$ \\
\hline & 3 & $\begin{array}{l}\text { Identification is almost complete and description } \\
\text { are arranged with almost proper connection }\end{array}$ \\
\hline & 2 & $\begin{array}{l}\text { Identification is not complete and description are } \\
\text { arranged with few misuse proper connection }\end{array}$ \\
\hline & 1 & $\begin{array}{l}\text { Identification is not complete and description are } \\
\text { arranged with misuse proper connection }\end{array}$ \\
\hline \multirow[t]{4}{*}{$\begin{array}{l}\text { Language } \\
\text { use }\end{array}$} & 4 & Very few grammatical or agreement in accuration \\
\hline & 3 & $\begin{array}{l}\text { Few grammatical or agreement in accuration but } \\
\text { not affect on meaning }\end{array}$ \\
\hline & 2 & Numerous grammatical or agreement in accuration \\
\hline & 1 & Frequent grammatical or agreement in accuration \\
\hline
\end{tabular}

(Gay, 1981)

The data was collected in this research analyze by using the procedures as follows:

1. Scoring the students correct answer of pre-test and post-test.

$$
\text { Students Score }=\frac{\text { The Number of Student's Correct Answer }}{\text { Total Score }} \times 100
$$

2. Calculating the mean score of the students' writing test used the following table:

$$
\begin{array}{ll}
\bar{X}=\frac{\sum x}{N} & \\
\text { Where }: \bar{X} & =\text { Mean Score } \\
\sum \begin{array}{ll}
\mathrm{X} & =\text { The sum of all scores } \\
\mathrm{N} & =\text { The total number of sample (Gay, 1981: 298). }
\end{array}
\end{array}
$$


3. To find out the improvement of percentage:

$$
\%=\frac{X 2-X 1}{X 1} \times 100
$$

Where, \%: the percentage of improvement

$\mathrm{X} 2$ : the total score of Post-test

$\mathrm{X} 1$ : the total score of Pre-test

(Gay, 1987)

4. Calculating the percentage of the students' score:

$$
\mathrm{P}=\mathrm{F} \times 100 \%
$$

$$
\text { Where: } \begin{aligned}
\mathrm{P} & =\text { Percentage } \\
\mathrm{F} & =\text { Frequency } \\
\mathrm{N} & =\text { The total number of students }
\end{aligned}
$$

5. Calculating the value of t-test to indicate the significance between post-test and pre-test, the researcher will use the formula as follow:

$$
\mathrm{t}=\frac{\bar{D}}{\sqrt{\frac{\sum \mathrm{D}^{2 \frac{\left(\sum \mathrm{D}\right)^{2}}{N}}}{N(N-1)}}} \quad \text { Where }: \bar{D}=\frac{\sum D}{N}
$$

Where: $\mathrm{t}=$ Test of significance

$\bar{D}=$ The mean of different score

$\sum \mathrm{D}=$ The sum of total score of significance

$\sum \mathrm{D} 2=$ The square of the sum for difference

$\mathrm{N} \quad=\quad$ The total number of subject (Gay, 1981:366).

\section{FINDINGS}

\section{The students mean score in writing recount text}

The findings of this research deal with the students' score. They are the mean scores of pre test and post test, the rate percentage and frequency of pre test and post test and the t-test value. These findings describe as follows:The improvement of students Content. The mean score of the students in pre test is (30) the mean score of post test was (79). Therefore, the use of T-Chart strategy can improve the students Content in pre test and post test. The students achievement in post test is greater than in pre test. 
The improvement of students Organizational. The mean score of the students in pre test is (39) and the mean score of post test was (76). Therefore, the use of T-Chart strategy can improve the students Organizational in pre test and post test. The students achievement in post test is greater than in pre test.

The improvement of students Language use. The mean score of the students in pre test is (29) and the mean score of post test was (66). Therefore, the use of T-Chart strategy can improve the students Language use in pre test and post test. The students achievement in post test is greater than in pre test.

\section{The score classification of students writing ability}

\section{a. Content}

\section{1) Pre test and Post test result}

The pre test is aimed to know the basic ability of the students writing. It was conducted in the twelfth grade students of SMA Negeri I Sungguminasa. The pre test involved 26 students who followed the pre test 2 students $(7.692 \%)$ got fair score, 23 students $(88.461 \%)$ got poor score and 1 students $(3.846 \%)$. It can be concluded that almost of students got fair scores in their writing.

The post test is conducted to know the result of the students score writing ability after giving treatment by using T-Chart strategy the 26 students who followed the post test 3 students (11.538\%) got fair score, 19 students $(73.076 \%)$ got good score, and 4 students $(15.384 \%)$ got excellent score. It means that the treatment was given to the students in the class was successful in improving the students ability.

b. Organization

\section{1) Pre test and Post test result}

The pre test is aimed to know the basic ability of the students writing. It was conducted in the twelfth grade students of SMA Negeri I Sungguminasa. The pre test involved 26 students who followed the pre test 15 students $(57.692 \%)$ got poor score, 9 students (34.615\%) got fair score, and 2 students (7.692\%). It can be concluded that almost of students got poor scores in their writing.

The post test is conducted to know the result of the students score writing ability after giving treatment by using T-Chart strategy, the 26 students who followed the post test 5 students $(19.230 \%)$ got fair score, 18 students $(69.230 \%)$ got good score, and 3 students $(11.538 \%)$ got excellent score. It means that the treatment was given to the students in the class was successful in improving the students ability.

c. Language use

\section{1) Pre test and Post test result}

The pre test is aimed to know the basic ability of the students writing. It was conducted in the twelfth grade students of SMA Negeri I Sungguminasa . The pre test involved 26 students who followed the pre test 24 students $(92.307 \%)$ got poor score, 1 student $(3.846 \%)$ got fair score, and 1 student (3.846\%) got good score. It can be concluded that almost of students got poor scores in their writing. 
The post test is conducted to know the result of the students score writing ability after giving treatment by using T-Chart strategy the 26 students who followed the post test 12 students $(46.153 \%)$ got fair score, 13 students $(50 \%)$ got good score, and 1 student $(3.846 \%)$ got excellent score. It means that the treatment was given to the students in the class was successful in improving the students ability.

\section{Test of significance testing}

The significance of students' ability in writing recount text to know the level of significance of the pre test and post test. The researcher used t-test analysis in the level of significance $\mathrm{p}(0.05)$ with the degree of freedom $(\mathrm{df})=\mathrm{N}-1$, where $\mathrm{N}$ number of subject (26) students then the value of t-table is 2.060

In other to know whether or not the mean score was different from two test (pretest and post-test), the writer used the t-table and indicates that the value of the t-test was higher than the value of the t-table $21.36>2.060$ It indicates that there was a significant difference between the result of the students' pre-test and post-test.

\section{DISCUSSION}

\section{Implementation of T-Chart Strategy}

The result of treatment of students activeness in teaching and learning process toward the implementation of T-Chart strategy to improve writing skill dealing with content, organization, and language use at the twelfth grade students of SMA Negeri I Sungguminasa which is conducted with pre test, treatment and post test during 6 meetings.

The implementation of T-Chart Strategy starts from the beginning until the end after knowing the result of score students' in write recount text. The main research is how the students can write recount text and concern in content, organization, and language use of text. At the based theory of T-Chart strategy, the researcher as successful communicator and create smart teaching to make the students interested.

The researcher creates enjoyable between researcher and students or conversely. Agree with the hardest things that people do to write because requires of thinking. The problem is how to refine ideas. The ideas can refine if the students ever feel that, they can remember and thinking what they want to write. Then the researcher gave the topic to the students and gave worksheet of T-Chart to help them in write recount text.

In improving the students writing ability the researcher used T-Chart strategy and the percentage improvement of the students' score in writing content. It is indicated from the improvement of mean scores in pre test from (30) to (79) in post test.

Based on the pre test result, the student score in writing content are from 26 students, none of the students got excellent and very good score. There were 23 ( 88 . $461 \%$ ) students got poor score, 2 (7. 692\%) students got fair score and 1 (3. 846\%) students got good score. And the post test 3 students (11.538\%) got fair score, 19 students $(73.076 \%)$ got good score, and 4 students (15.384\%) got excellent score. It 
means that the treatment was given to the students in the class was successful in improving the students ability.

The data described the most of them success to improve their score into writing content by using T-Chart strategy. This improvement is also followed by the significance. The t-test value (21.36) is greater than t-table (2.060) for the degree of freedom (0. 05). It means that the null hypothesis $(\mathrm{Ho})$ was rejected and alternative Hypothesis $\left(\mathrm{H}_{1}\right)$ was accepted. Based on the data are shown above, it can be concluded that the students writing score in term of content in recount text of the eleventh grade of SMA Negeri I Sungguminasa.

\section{CONCLUSION AND SUGGESTION}

This chapter consists of two sections, the first section deals with the conclusion of findings of the research and the other one deal with suggestion.

\section{a. Conclusion}

Based on the finding and discussion in the previous chapter, the researcher concludes that:

1. The use of T-Chart strategy is effective to improve the students' writing ability in terms of content, organization, and language use. It is proved by the mean score of post test (73. 66) which is higher than the mean score of pre test (32. 66). It means that learning by $\mathrm{T}$-Chart strategy is effective to improve the students' writing ability

2. There is a significance difference between the students' writing ability before and after using T-Chart strategy in writing process. It is proved by the result of the statistical analysis at the significant level 0.05 which indicates that t-test value for content, organization, and language use is 21.36 , it is greater than ttable value $2.060(21.36>2$. 060). Based on the result, hypothesis shows that $\mathrm{H}_{0}$ is rejected and $\mathrm{H}_{1}$

\section{b. Suggestion}

Based on the result of the data analysis and conclusion, the researcher suggests as follows:

1. It is suggested to the English teachers to use T-Chart strategy as the alternative in the teaching and learning process to improve the students' English skill especially in improving their writing ability.

2. The students are excepted improve their intensity in learning writing through TChart strategy.

3. This strategy can be used as an additional strategy or further research with different discussion for the next researcher. 


\section{REFERENCES}

Adelstein, M.M.E.Pival J.G. 1980. The Writing Commitment. New York. Doc. Retrieved from (http://edutechwiki.unige.ch/en/Writing). Accessed on November $2^{\text {nd }}, 2011$.

Chang, K., Sung, Y., \& Chen, I. (2002) The effect of concept mapping to enhance text comprehension and summarization. The Journal of Experimental Education, 77 (1), 5-23.

DiCecco, V. M. \& Gleason, M. M. (2002) Using graphic organizers to attain relational knowledge from expository text. Journal of Learning Disabilities, 35, 306-320.

Graves and Fournier, D.N., M.F. (2002) Scaffolding adolescents' comprehension of short stories. Journal of Adolescent and Adult Literacy, 46(1), 30-39.

Foo, Ng. Mun, et al. 2008. Creative English Workbook. Jakarta: penerbit Erlangga

Gay, J.B. 1981. Educational Research for Analysis and Allocation, Second Edition, London : Longman

Indrayani, Mastira. (2007) Improving Students' Ability to write descriptive paragraph by using photographs. Thesis S1, UNM Makassar.

Kirylo, J.D. \& Millet, C.P. (2000) Graphic organizers: an integral component to facilitate comprehension during basal reading instruction. Reading Improvement, 37, 179-1 86.

Litasari, Linda. 2010. An experimental study on the use of picture series in teaching writing narrative text. Thesis. FKIP Universitas Lambung Mangkurat

Oshima, Alice and Ann Hogue. 1997. Introduction to Academic Writing. London and New York: Longman Group UK Limited.

Peha, Steve (1995-2003),. Teaching That Makes Sense (TTMS). Available at: www.ttms.org

Robinson, D.H., Katayama, A.D., DuBois, N.F., \& Devaney, T. (1998) Interactive effects of graphic organizers and delayed review on concept application. The Journal of Experimental Education, 67(1), 17-31.

Widiyani, Erlik. 2010. The effectiveness of clustering technique to teach writing skill viewed from students' linguistic intelligence. Thesis. Sebelas Maret University of Surakarta. 